\title{
Global Recession and Diamond Industry Workers: A Socio Economic Perspective
}

\author{
Vinod Sen, Ph. D.* , Mukesh Kumar Solanki** and Jadhav Kishor Kisan**
}

\begin{abstract}
The recent globalization recession (2007-08) and its effect is all pervasive, the only difference is of magnitude. Gems and Jewelry is of the largest contributor in India's total export. Out of this total export of India diamond contributes more than 12 per cent. Gujarat is the one of the biggest player in diamond processing (cutting and polishing) and contributes about 72 per cent of the total exports of India. As diamond industry is mainly export based industry, during recession it adversely gets affected. This paper is an attempt to evaluate the effect of the global slowdown on the cutting and polishing worker. The paper is a case study of diamond industry workers of Surat based on the primary and secondary data that has been collected from 100 diamond cutting and polishing workers of the diamond industry located in Surat of Gujarat. The paper comes up with the conclusion that the recent recession adversely affected the socio-economic condition of the diamond worker and the scheme of social and economic benefits to the effected people fails miserably to support.
\end{abstract}

Keywords: Global recession, diamond Industry, trade \& employment and wage

\section{INTRODUCTION}

In the modern world, this is not the time for any nation to survive in isolation. Globalization itself is neither good nor bad. It has the power to do enormous good for developing countries. But the limitations of globalization cannot be ignored in any circumstances. In the globalized market scenario, the impact of economic unrest in one part of the world percolate down to all countries as they are involve in trade with each other. The impact of economic unrest is more acute on the countries/ Industries involve heavily on international trade. The recession (2007-09) leads to over spread unemployment and therefore reduction of purchasing power in the hands of public due to job loss and reduction in wages/salaries. Out of the total export of India gems and jewelry occupied a dominant position. India contributes about 80 per cent of the total diamond cutting and polishing of the world market. The average annual production of the diamond industry is around 78,000 carats (2005-07) in India. India has exported about 80 to 85 per cent and between 15 to 20 per cent is consumed at home (Hirway, 2009). The out of total share of cut and

\footnotetext{
*Dr. Sen is Assistant Professor at Centre for Studies in Economics and Planning , School of Social Sciences, Central University of Gujarat, Gandhinagar, Gujarat. Email: senvinod79@gmail.com

**Mr. Solanki and Mr. Kisan are currently Research Scholar at the Centre for Studies in Economics and Planning
} 
polished diamond 25 per cent were exported directly to United States of America, 25 per cent to HongKong, 10 per cent to Belgium, 5 per cent to Israel and around 2 per cent each to Japan and Thailand. USA is one of the major buyers of diamond. It is clear when the recession has started in USA obviously, impacted of export or import of diamond sector and ultimately the diamond industry of the country.

The states of Tamil Nadu, Kerala, Maharashtra, Rajasthan and Gujarat are the main centers where the processing of raw diamonds is done on a large scale. However, the lion's share of markets for this activity is taken away by Gujarat alone, in India. In state of Gujarat, Surat, Ahmadabad, Mahesana, Banaskantha, Patan, Rajkot, Amreli, Junagadh and Bhavnagar are the centers where cutting, polishing and the processing of raw diamonds is done. However, the lion's share of markets for this activity is taken away by Surat alone in Gujarat. Out of every variety of 12 diamonds made in the world out of these 11 made in Gujarat diamond industries. It shows that India has established itself as the world's largest diamond processing centre.

This paper is an attempt to evaluate the socio-economic condition of the workers in diamond cutting and polishing industries. Moreover an attempt is also made to evaluate the social schemes and programs formulated for safeguarding the benefits of these workers.

\section{DATA AND METHODS}

The primary data has been collected through a structured questionnaire/unstructured interview from Surat district. The sample size for the study included 100 workers households 50 each from Varaccha and Katargam areas of the district. Simple tabular analytical techniques have been followed to analyse the collected data.

\section{RESULTS AND DISCUSSION}

\section{Socio-Economic and Demographic dimension}

To evaluate the effect of recession on the workers one must have the idea of socio-economic conditions of the workers. Most of the processing units are owned by the upper caste communities. The workers in these units are migrants from different parts of India specially Uttar Pradesh, Maharashtra, Madhya Pradesh and Bihar. From the table 1 it can be noted that there is wide difference in labor participation rate gender wise but there is also wage discrimination among male and female workers for the same nature of jobs. The facts from the field survey reveal that the participation of women are sparse and confined to low wage earning activities only. It can be further noted that 57.6 per cent of the worker is not earning anything out of which 36.1 per cent are females and 21.5 are mails. Moreover, most of the employed women are earning just 1000 to 2000 per month. The mails are earning comparatively higher and they are employed batter.

Table 1: Gender and Monthly Family Income

\begin{tabular}{|c|c|c|c|c|c|c|c|}
\hline \multirow[b]{2}{*}{$\begin{array}{l}\text { Gender of Family } \\
\text { Member }\end{array}$} & \multicolumn{6}{|c|}{ Monthly Income of Family Members } & \multirow[b]{2}{*}{$\begin{array}{l}\text { Total } \\
(\%)\end{array}$} \\
\hline & $\begin{array}{l}1000 \quad \text { to } \\
2000\end{array}$ & $\begin{array}{l}2000 \quad \text { to } \\
5000\end{array}$ & $\begin{array}{l}5000 \quad \text { to } \\
7000\end{array}$ & $\begin{array}{l}7000 \quad \text { to } \\
10000\end{array}$ & $\begin{array}{ll}\mathrm{Up} & \text { to } \\
10000\end{array}$ & $\begin{array}{l}\text { Not } \\
\text { Earn } \\
\text { ing }\end{array}$ & \\
\hline Male & .7 & 7.5 & 8.2 & 16.9 & 5.6 & 21.5 & 60.4 \\
\hline Female & 2.8 & .0 & .5 & .2 & .0 & 36.1 & 39.6 \\
\hline Total & 3.5 & 7.5 & 8.7 & 17.1 & 5.6 & 57.6 & 100 \\
\hline
\end{tabular}

Source: Field Survey, 2011. 
The educational status of the workers involve in cutting and polishing of diamond is one of the most important reasons that they are low paid and are involve as very elementary activities. The wages paid to them are low. Out of the respondents more than 55 per cent have basic education up to class $5^{\text {th }}$. The table 2 explains the educational status of the workers. Out of the total respondents 23.9 percent are illiterate while 69.8 per cent were educated up to class $10^{\text {th }}$ only.

Table 2: Educational Status of the workers (Family Members)

\begin{tabular}{|l|c|c|c|c|c|}
\hline \multirow{2}{*}{ Gender of Family Member } & \multicolumn{4}{|c|}{ Education of family member } & \multirow{2}{*}{ Total } \\
\cline { 2 - 5 } & Illiterate & Up to V & VI to X & Above XI & \\
\hline Male & 8.7 & 20.6 & 26.0 & 5.2 & 60.4 \\
\hline Female & 15.2 & 12.2 & 11.0 & 1.2 & 39.6 \\
\hline \% of Total & 23.9 & 32.8 & 37.0 & 6.3 & 100 \\
\hline
\end{tabular}

Source: Field Survey, 2011

On the other hand, just 6.3 per cent of workers are having education above class $12^{\text {th }}$. The condition of female is worse as out of the total illiterate 15.2 per cent are females. Lack of proper education to workers restricts them to avail the benefits of social security and other benefits offered to them by the center and state government.

\section{Recession and its Impact on Employment of Diamond Workers}

Most of diamond industries collapsed during the recession and workers have gone through the phase of joblessness. Lack of access to any reliable support and the struggle to make ends has an adverse impact on the family life of the workers. During the recession there was a drastic cut down not only diamond industry but also in other industries. Therefore, it is very difficult to diamond workers to search other alternative jobs or employment opportunities.

Table 3: Effect of Recession on Workers in Diamond industry (on job)

\begin{tabular}{|l|c|c|}
\hline No. of Months Jobless & No. of Workers Jobless & Percentage \\
\hline 6 month & 61 & 69.32 \\
\hline 12 month & 22 & 25 \\
\hline 18 month & 5 & 5.68 \\
\hline Total & 88 & 100 \\
\hline
\end{tabular}

Source: Primary Field Survey, 2011

The table 3 reveals about 88 per cent workers lost their job from 6 month to 18 months. In which around 70 per cent workers were jobless for the period of 6 months and 25 per cent workers were without job for 12 months and around 6 per cent workers reported that they were jobless for 18 months during the recession. Those who lost their job they have managed to find work outside the industry. The major jobs outside the industry were the embroidery industry, casual unskilled work and mostly jobless workers have gone to their villages and involved themselves at agriculture and other rural activities. It means that 
there is no job security in diamond industries existence and any unwanted fluctuation since diamond trade completely depend upon international market.

\section{Recession and Economic Situation}

During recent recession the wide spread tendency is decline in level of employment. During and before recession it was observed that the diamond industry also faced the problem of shut down. During this period the overseas market collapsed and also had the adverse effect on Indian diamond industries. As the lack of diamond demand, the panic among diamond unit worker accelerates and forces them to stop production. So during this phase there were wide evidences of job cuts and reduction in wage rate. The fact from the primary data shows overall change in the wage scenario in post economic crisis. The pre and post crisis wage level provides the real picture of the nastiest condition of worker.

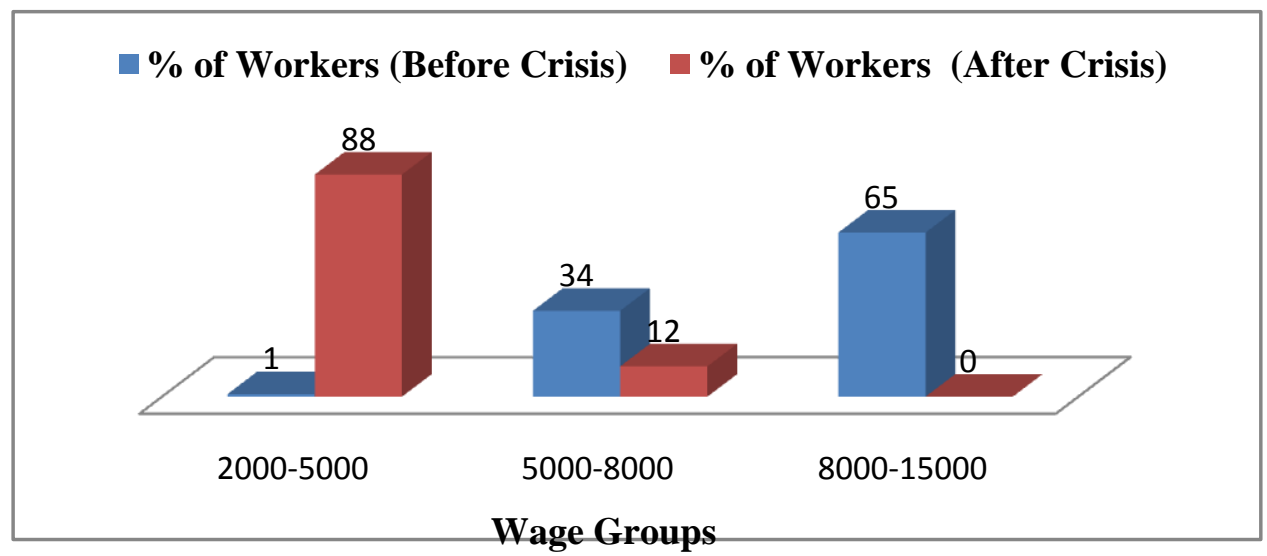

Figure 1: Wage and Employment

As it is clear from figure 1.1 that before crisis 1 per cent worker is earning monthly income 2000 to 5000 but after recession 88 per cent workers are earning the monthly wage of Rs.2000-5000. It can be clearly noticed that the most of these workers are having monthly income much lower than the pre meltdown period. Before recession around 65 per cent workers were earning Rs.8000-15000 but after recession, none of workers are able to earn Rs.8000-15000 per month. The general decline in the wage rates has been due to the fact that the workers who have remained in the industry now settle for lower wages and the proportion of workers in the low wage classes has increased when compared to pre crisis. Expenditure also declines significantly during the post recession period. The reaction of respondent is explained with the table 4 .

Table 4: State of Household Expenditure

\begin{tabular}{|l|l|}
\hline Household Expenditure & No. of Household \\
\hline Decrease & 73 \\
\hline Not Decrease & 27 \\
\hline Total & 100 \\
\hline
\end{tabular}

Source: Field Survey, 2011 
Global Recession and Diamond Industry ...../51

The table 4 depicts that most of the people fail to manage the standard of living during post recession. About 73 per cent of the people accept that they were forced to reduce the expenditure as the income declines or job loss. The either of the conditions be inflation or recession is going to influence the 'aam aadmi' the most. Same is the situation of polishing and cutting workers during the recession. Those jobless in diamond industries have been undergoing economic stress driven psychological disaster.

\section{Financial relief and accessibility for workers}

During recession, the demand of diamond declines and forces the producers to shut down or reduce the production. This resulted to wide unemployment among the diamond workers. Jobless workers during recession fail to get the alternative sources of earning and support the family. Along with the financial support, the training programs were also introduced to enhance the skill of workers who lost their jobs during recession. According to the Task force for Diamond sector, RBI 2009 has introduced some social security schemes for forcefully unemployed diamond workers. But the conducting to the field survey to find out the welfare schemes among the workers knowledge, the following analysis has been reexamining to explore the impact of social security schemes. To help them (jobless workers) Government of Gujarat has announced some social security schemes. A suitable training program was organized at district level by the district administration to train displaced diamond workers for alternative employment. The district authorities may also identify and sponsor all eligible workers for appropriate financial assistance, loans under various Government Schemes. In order to address this government has started a Scheme for the unemployed diamond workers known as Ratnadeep skill enhancement training assistance package' during 2009.

\section{Effectiveness and Accessibility of Benefits}

Some special social security schemes and programs was formulated for diamond industry workers i.e. Vajpayee Bankable Yojana (VBY), Swarnajayanti Shahari Rozgar Yojana (SJSRY), Prime Minister Employment Guarantee Programme (PMEGP) etc., for the welfare of the workers but field data show that none of the schemes was implemented in the field area properly. There are provisions that workers will be some minimum days of employment in given year. For this the pre requirement is the availability of the job card. None of the workers in the study area are having job cards. Job card is very important document to claim benefits of social security without which workers are helpless and they are disallowed for the benefit of any social security schemes. The performance of any schemes or programs depends on the implementing authorities. Now it is a duty of labor commissioner to implement the existing rules and regulation but they are failed to do so.

Table 5: Awareness of Social Security Schemes

\begin{tabular}{|c|c|c|c|}
\hline \multirow{2}{*}{$\begin{array}{l}\text { Working } \\
\text { Experience }\end{array}$} & \multicolumn{2}{|c|}{ Knowledge of Social welfare schemes } & \multirow[t]{2}{*}{ No. of total workers } \\
\hline & Yes & No & \\
\hline 0 to 3 & 0 & 2 & 2 \\
\hline 3 to 5 & 3 & 27 & 30 \\
\hline 5 to 10 & 0 & 30 & 30 \\
\hline 10 to 15 & 0 & 10 & 10 \\
\hline Above 15 years & 0 & 28 & 28 \\
\hline Total & 3 & 97 & 100 \\
\hline
\end{tabular}

Source: Field Survey, 2011 
Announcing the schemes and program was essential for safeguarding the workers and their families who are dependent on them for their livelihood. The schemes and programs are good but whether the benefits reached to the targeted ones or not is crucial to be evaluated. Most of the workers as mentioned in the table 2 are hardly educated. So the chances are that they fail to have access of the benefits specially offered to them by the Government.

It is normally believed that work experience give inside knowledge of company, rules and regulation and the schemes but ground reality fails to support. The facts in table 5 also show that the level of experience and awareness about social security schemes have nothing to do as those who having 5 to 15 years of experience did not have any knowledge about the schemes and benefits provided to them. One important attention required is that during recession diamond association and other non-governmental organizations (NGOs) were working for the benefit of diamond workers but their effort was not efficient enough and failed to deliver the expected result. One of the epoch-making reasons for the failure of these benefit schemes is the low educational level of the workers. As out of the total workers only 3 per cent of them have knowledge of the social welfare schemes. Thus, lack of knowledge of social security schemes and lack of awareness of labor law resulted to miserable condition of the diamond industry workers. The workers are highly unsatisfied about the implementation of the schemes.

Table 6: Reasons for Low Implementation of Social Welfare Schemes \& Programs

\begin{tabular}{|l|l|}
\hline Reason for low implantation & No. of workers \\
\hline Non Availability of Document & 22 \\
\hline Lack of Awareness & 36 \\
\hline Lack of Support Trade Unions \& Organisations & 14 \\
\hline Don't Know & 28 \\
\hline Total & 100 \\
\hline
\end{tabular}

Source: Field Survey, 2011

The workers fail to avail the benefits of the welfare schemes as most of the diamond industries are unregistered with government so that they are free from the supervision of implementation authorities and it is very difficult to force them to implement the social welfare schemes and programs. Out of the total respondents no one is satisfied with the implementation part of the welfare programs as they fail to the reach to the targeted ones. When asked to the respondents about the reasons for poor implementation, responses were startling. Table 6 explains the reasons for low implementation. The main reasons are like inappropriate documents, unawareness, and lack of support by trade unions and organizations. About 36 per cent respondents were even not aware of the programs specially formulated for safeguarding the benefits of these workers. Even some (22\%) fails to avail the benefits because of non availability of required documents and 14 per cent respondents state the ineffectiveness of trade unions and organizations responsible for poor implementations. 
Global Recession and Diamond Industry ...../53

\section{CONCLUSION}

No doubt recent recession impacted almost all economies of the globe but the intensity differs among them. Diamond industry which is more inclined toward international trade reflects the worse picture of Surat as compared to the some other sectors of the economy. More precisely the most badly affected were the workers at the cutting and polishing industry. Even the intensity differs in different social groups. The reality from the study area explains the worse condition of workers during recession. In the globalization phase the labor and labor market are prone to influenced by international market movements. The workers social- economic conditions get mare substandard because of reduced wages, joblessness and long working hours. It was noticed that during recession government has announced social welfare schemes for those who are jobless. But the survey experiences and data analysis reveal the fact that social welfare schemes was total failure in Surat diamond industries. The workers are economically and socially weak so government and organizations should have to enhance the awareness among workers. What is needed at the very first is that the units should be made registered. Last but not least the policy of the government must be within the accessibility of the targeted workers which is essential for proper implementation of policies.

\section{REFERENCE}

Acharya, Shankar (2009). "Global Crisis and India", New Delhi, Academic Foundation.

Annual Report (2009-2010). "Socio-Economic Review”, Directorate of Economic and Statistics, Government of Gujarat, Gandhinagar.

(2010-2011). "Socio-Economic Review", Directorate of Economic and Statistics, Government of Gujarat, Gandhinagar.

Census of India (2011). Provisional Results, http://censusindia.gov.in/2011-common/ censusdataonline.html, Accessed on 2012/10/11.

Desai, Kiran and N. Raj (1999). "Child Labor in the Home-Based Industries in the Wake of Legislation The Case of Diamond industry of Surat” Centre for Social Studies, Surat \& V.V. Giri National Labor Institute, Noida.

Hirway, Indira (2009). "Losing the Sparkle: Impact of the Global Crisis on the Diamond Cutting and Polishing Industry in India", UNDP, India.

Report (2010). "Effect of Economic Slowdown on Employment in India”, Chandigarh: Ministry of Labor \& Employment.

Sahoo, Sarbeswara (2010). 'Impact of Global Recession on the Livelihood of Diamond Workers: a case study of Gujarat, India. http://www.global-labour-university.org [Accessed on 15 April 2010]. 